\title{
Gangliocytic Paraganglioma of the Filum Terminale. A Rare Entity
}

\section{Paraganglioma gangliocítico do filum terminale. Uma entidade rara}

\author{
Sofia Isabel Carneiro Pereira Guerra Tavares ${ }^{10}$ Gonçalo Maria Sengo Agante Guerreiro Costa1(1) \\ ${ }^{1}$ Department of Neurosurgery, Centro Hospitalar e Universitário de \\ Coimbra, Coimbra, Portugal \\ Arq Bras Neurocir 2021;40(1):86-90. \\ Address for correspondence Sofia Isabel Carneiro Pereira Guerra \\ Tavares, MSc, Department of Neurosurgery, Centro Hospitalar e \\ Universitário de Coimbra, Praceta Professor Mota Pinto, 3000-075 \\ Coimbra, Portugal (e-mail: sofia.icpg.tavares@gmail.com).
}

\begin{abstract}
Keywords

- paraganglioma

- gangliocytic

- filum terminale

- low back pain
\end{abstract}

\section{Resumo}

received

April 10, 2020

accepted

August 5, 2020

published online

October 16, 2020
Paragangliomas are rare, benign and slow-growing neuroendocrine tumors that can arise from the adrenal medulla (85-90\%) or from the extra-adrenal paraganglia. In the central nervous system (CNS), they can be found at several sites, but more often at the cauda equina and filum terminale region, where they account for between 2.5 and $3.8 \%$ of total tumor cases of that region. There are only 8 cases described in the literature that mention the presence of the gangliocytic variant of this entity at the filum terminale.

We present the case of a 41-year-old man with chronic lumbar pain refractory to medical treatment, without any associated neurological deficits. Magnetic resonance imaging (MRI) revealed an intradural, extramedullar oval lesion with regular contours and homogeneous caption of contrast at L1 level.

He was submitted to surgical treatment, with complete resection of the lesion. The histological analysis revealed a gangliocytic paraganglioma of the filum terminale. At 5 years of follow-up, he remains asymptomatic and without any signs of relapse.

These are lesions with an overall good prognosis with gross total resection. Although the recurrence rate is extremely low, prolonged observation is recommended due to the slow-growing nature of the tumor, being estimated that between 1 and $4 \%$ can recur even after gross total removal.

Os paragangliomas são tumores neuroendócrinos raros, benignos e de crescimento lento, que podem ter origem na medula adrenal (85-90\%) ou nos paraganglia extraadrenais.

Podem ser encontrados em diversas localizações no sistema nervoso central (SNC), mas mais frequentemente a nível da cauda equina ou no filum terminale, onde correspondem a entre 2,5 e 3,8\% do número total de tumores dessa região. Existem

October 16. 2020

DOI https://doi.org/ 10.1055/s-0040-1718426. ISSN 0103-5355.

\footnotetext{
(c) 2020. Sociedade Brasileira de Neurocirurgia. All rights reserved. This is an open access article published by Thieme under the terms of the Creative Commons Attribution-NonDerivative-NonCommercial-License, permitting copying and reproduction so long as the original work is given appropriate credit. Contents may not be used for commercial purposes, or adapted, remixed, transformed or built upon. (https://creativecommons.org/ licenses/by-nc-nd/4.0/) Thieme Revinter Publicações Ltda., Rua do Matoso 170, Rio de Janeiro, RJ, CEP 20270-135, Brazil
} 


\section{Palavras-chave \\ - paraganglioma gangliocítico \\ - filum terminale \\ - dor lombar}

apenas 8 casos descritos na literatura que descrevem a presença da variante gangliocítica desta entidade no filum terminale.

Apresentamos o caso de um homem com 41 anos de idade com dor lombar crônica refratária ao tratamento médico, sem qualquer déficit neurológico associado. A ressonância magnética (RM) demonstrou uma lesão oval intradural e extramedular, de contornos regulares, com captação homogénea de contraste localizada ao nível de L1.

O paciente foi submetido a intervenção cirúrgica, tendo sido feita uma resseção completa da lesão. A análise histológica revelou um paraganglioma gangliocítico do filum terminale. Aos 5 anos de seguimento, o paciente permanece assintomático e sem sinais de recidiva.

Estas são lesões com um bom prognóstico após uma remoção macroscopicamente total. Embora a taxa de recidiva seja muito baixa, a vigilância prolongada é recomendada devido ao crescimento lento destes tumores, sendo estimado que entre 1 e $4 \%$ podem recidivar mesmo após uma remoção total.

\section{Introduction}

Paragangliomas are rare, benign and slow-growing neuroendocrine tumors that can arise from the adrenal medulla (85$90 \%$ ) or from the extra-adrenal paraganglia. ${ }^{1}$ They derive from the migration of neural crest cells that constitute the sympathetic and parasympathetic nervous system (CNS). ${ }^{2}$ Sympathetic paragangliomas are usually secretory and produce catecholamines, while parasympathetic paragangliomas tend to be nonsecretory.

Extra-adrenal paragangliomas can arise anywhere in the sympathetic and parasympathetic chain of ganglia, ${ }^{1}$ and occur commonly $\left(\sim 90 \%^{3}\right)$ in the neck and head region (mainly from the carotid bodies or glomus jugulare ${ }^{4}$ - predominantly of parasympathetic nature ${ }^{1}$ ). In the CNS, they can be found at several sites such as the sella turcica, the cavernous sinus, the pineal gland, the pituitary gland, the cerebellopontine angle and the petrous ridge, ${ }^{5}$ but more often at the cauda equina and filum terminale region, ${ }^{6}$ where they account for between 2.5 and $3.8 \%$ of the total tumor cases of that region. ${ }^{5}$ The mean age of presentation is around between 40 and 60 years old with a slight male predominance. $^{5}$

They are histologically characterized by an arrangement of chief cells with an abundance of neurosecretory granules, placed in lobules surrounded by sustentacular cells, ${ }^{1}$ designated as a Zellballen pattern.

Extra-adrenal paragangliomas may develop a gangliocytic component (gangliocytic paragangliomas), which consist of ganglion cell components in addition to the sustentacular cells. ${ }^{1}$ The diagnosis is confirmed with immunohistochemical staining of the specimens. ${ }^{1}$

The combination of their location at the filum terminale with the gangliocytic histological variant creates an extremely rare entity, with only 8 cases described in the literature until now, including the present one.

\section{Case Description}

We present a case of a 41-year-old man with recurrent episodes of low back pain irradiating to his lower limbs, with increasing frequency and intensity associated with a sensation of tingling in his legs, with nearly 1 year of evolution. At the physical examination, there was no evidence of bowel or bladder incontinence, sensitive or motor deficits or gait disturbances.

Magnetic resonance imaging (MRI) revealed a well-circumscribed, oval shaped, intradural extramedullar expansive lesion with $\sim 1,6 \times 1,2 \mathrm{~cm}$ of diameter. It revealed isointense at T1-weighted images, and slightly heterogeneous at T2-weighted images with a discrete hyperintense core. After gadolinium administration, an intense and homogenous enhancement
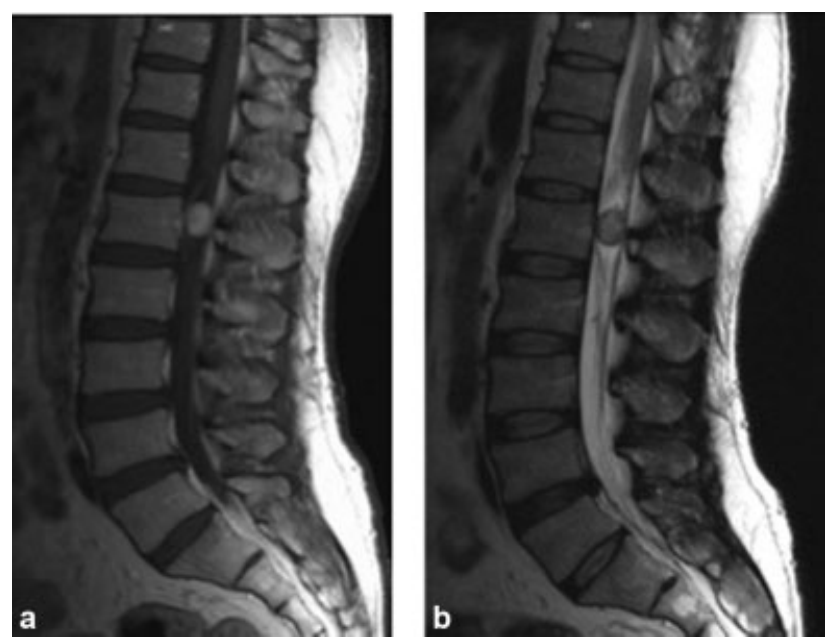

Fig. 1 Magnetic resonance imaging features an oval intradural lesion at L1 level: (a) T2-weighted showing an isointense, slightly heterogeneous wellcircumscribed lesion at L1 with a discrete hyperintense core. (b) T1weighted with gadolinium enhancement showing homogenous contrastenhancement and a small serpentine upper pole vessel (blue arrow). 


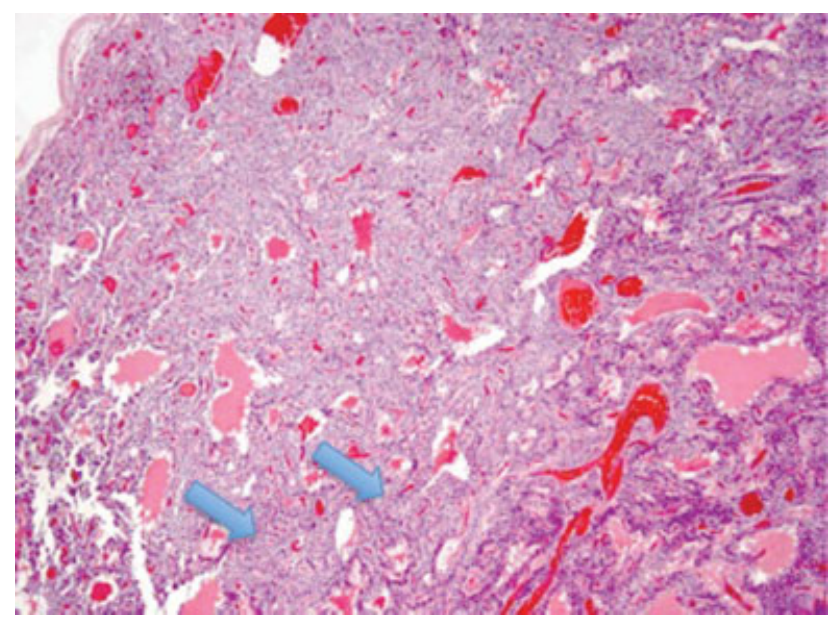

Fig. 2 Hematoxylin and eosin 40x amplification: Typical nested arrangement of cells in a Zellballen pattern (blue arrow), showing trabeculae and cords of cells within a fibrovascular stroma.

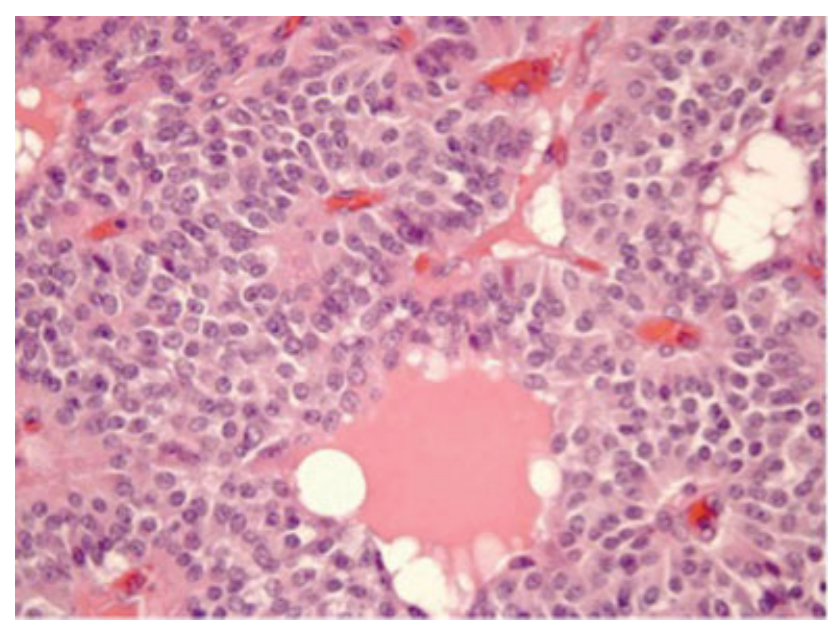

Fig. 3 Hematoxylin and eosin 400x amplification: Chief cells with a big cytoplasm area with an abundance of neurosecretory granules.

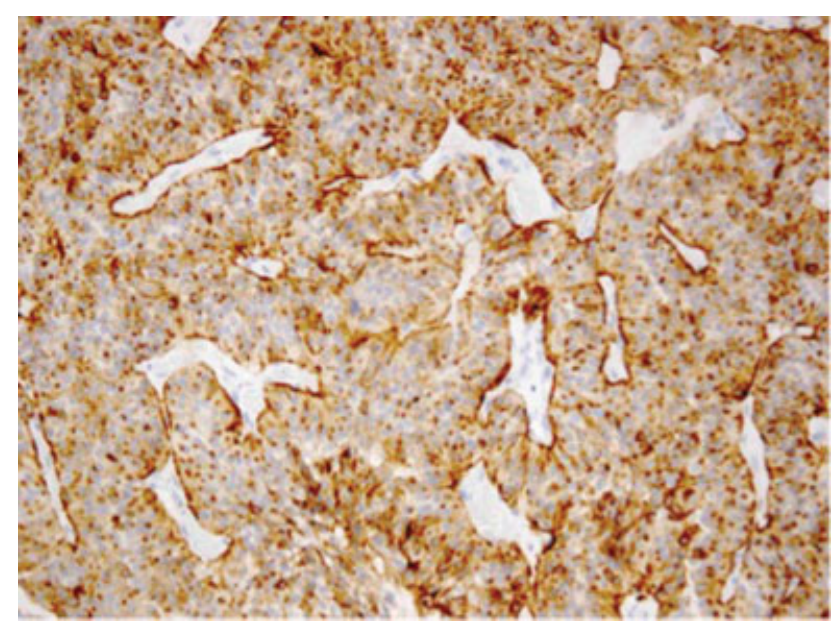

Fig. 4 Cromogranine A positive stain 200x amplification demarcating the cytoplasm of ganglion cells. The reticular organization can be seen.

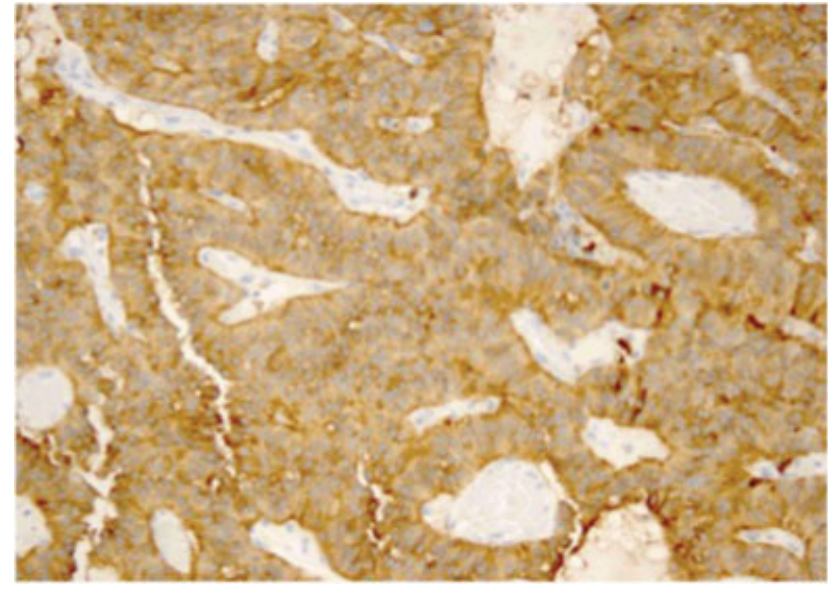

Fig. 5 Synaptophysin stain positive (brown) with 200x amplification.

was noted, as shown in - Fig. $\mathbf{1 b}$, where a small serpentine-like vessel can be observed on the upper pole of the tumor.

The patient was submitted to surgery, being performed a laminectomy of $\mathrm{L} 1$ and a microsurgical complete resection of the tumor. The lesion was an exophytic encapsulated intradural mass that distorted and expanded the nerve roots but was not attached to them. The filum terminale was easily identified by its distinct appearance and verified by neurostimulation. The tumor was undetachable from it, being needed its careful sectioning. There was no need for dural repair since the surgery was uneventful.

The patient referred an immediate relief of the paresthesias and lower limb pain in the postoperative period. As seems to be the rule for paragangliomas of this location, there was no clinical sign of any associated catecholamine release syndrome. ${ }^{4}$

The histologic analysis of the lesion revealed an arrangement of chief cells with an abundance of neurosecretory granules, organized in lobules surrounded by sustentacular cells, ${ }^{1}$ forming a Zellballen pattern, typical of paragangliomas - -Figs. 2 and 3. Additionally, immunopositivity for neuroendocrine markers - chromogranin A (-Fig. 4) and synaptophysin (-Fig. 5) - supported this histological diagnosis. The presence of ganglion cell components in addition to the sustentacular cells confirmed the diagnosis of a gangliocytic paraganglioma.

At 5 years postoperatively, the patient remains asymptomatic, maintaining imagiological surveillance without any signs of relapse.

\section{Discussion}

Paragangliomas are solid, well-encapsulated, highly vascular, slow-growing neuroendocrine tumors arising from specialized neural crest cells. $^{5}$

The first case of a paraganglioma of the cauda equina region was published in 1970, even though the authors initially defined the lesion as a "secretory ependymoma"; so, the first authors to precisely define this tumor were Lerman et al in $1972 .^{3,12}$ Since then, $\sim 220$ cases have been reported. ${ }^{3}$ However, only 8 cases with gangliocytic 
Table 1 Described cases in the literature of gangliocytic paragangliomas of cauda equine/filum terminale from the most recent to the first one described

\begin{tabular}{|c|c|c|c|}
\hline $\begin{array}{l}\text { Reported cases } \\
\text { in literature }\end{array}$ & Clinical Findings & Location & Degree of resection \\
\hline Current case & Low back pain and sciatica; No neurological deficits & L1 & Total gross resection \\
\hline 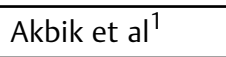 & Temporary urinary incontinence, perineal paresthesias & S1-S2 & Total gross resection \\
\hline Vural et $\mathrm{al}^{7}$ & Low back pain, sciatica & L4 & Total gross resection \\
\hline Llena et $\mathrm{al}^{8}$ & Low back pain, LE weakness & L1 & Total gross resection \\
\hline Matschke et al ${ }^{9}$ & Low back pain & Cauda equina & Total gross resection \\
\hline Djindjian et al $^{4}$ & $\begin{array}{l}\text { Low back pain, sudden paraplegia following } \\
\text { sacral infiltration of medication }\end{array}$ & L2-L5 & Total gross resection \\
\hline Mishra et $\mathrm{al}^{3}$ & & Unknown & Unknown \\
\hline Moran et al ${ }^{10}$ & & Unknown & Unknown \\
\hline
\end{tabular}

variations have been reported, including the present one, as summarized in - Table 1.

\section{Clinical Features}

Spinal paragangliomas usually manifest with nonspecific symptoms. ${ }^{11}$ Low back pain with or without radiculopathy is the most common presentation (50\%) and motor or sensory deficits can be present in $<10 \%$ of the patients. ${ }^{5}$ Bowel or bladder incontinence is quite rare (3\%) though some authors reported a higher frequency of sphincter and genital disturbance, compared with other tumors of this region. ${ }^{5}$ Despite their neuroendocrine origin, they rarely have functional hormonal activity or manifestations. ${ }^{3}$ However, there are some cases of paragangliomas with functional hormonal activity that can induce perioperative vital instability. ${ }^{3}$

No significant correlation was observed between the duration of symptoms and tumor dimension. ${ }^{5}$ In the literature, there are only two described cases of an acute flaccid paraparesis/cauda equine syndrome secondary to an intratumoral hemorrhage. ${ }^{5}$

These lesions are commonly encountered at the $4^{\text {th }}$ and $5^{\text {th }}$ decades of life, with a male predominance, and they are sporadic neoplasms, ${ }^{5}$ although $\sim 1 \%$ of cases are autosomal dominant. $^{2}$

Paragangliomas are most worrisome when located in the head and neck region because of their ability to infiltrate cranial nerves in this area. ${ }^{1}$ Paragangliomas in the cauda equina are similar in nature, but generally are well-demarcated intradural or extradural masses that do not infiltrate the spinal cord, soft tissues, or adjacent bone structures. ${ }^{1}$

The literature reports an extremely low recurrence rate, sometimes occurring 9 years after surgery, ${ }^{1}$ and it is estimated that between 1 and $4 \%$ can recur following gross total removal. ${ }^{5}$ This supports the need for prolonged observation due to the slow growing nature of the tumor. With subtotal resection, $10 \%$ of cauda equina paragangliomas will recur 1 year following surgery, which is why radiotherapy is recommended after a subtotal resection. ${ }^{5}$

Because of their benign natural history, observation can be a reasonable option in asymptomatic cases, and an overall good prognosis with gross total resection can be expected. However, close clinical follow-up is needed both to rule our more aggressive lesions and due to the potential for growth. ${ }^{1}$

\section{Imagiological Features}

Magnetic resonance imaging is the gold standard radiological exam for the diagnosis and follow-up of paragangliomas of the cauda equina or of the filum terminale. ${ }^{5}$ They may appear as hypo- to isointense on T1-weighted images, hyperintense on T2-weighted images, and vividly enhancing on contrasted studies. $^{1}$

These spinal tumors have no pathognomonic features, and other tumors of the cauda equina, including meningioma, schwannoma, and myxopapillary ependymoma, can have similar imaging profiles making histologic examination key to diagnosis. ${ }^{1}$

Paragangliomas are vascular tumors, and the identification of features reflecting this quality is crucial. ${ }^{6}$ On T2weighted sequences, intra and peritumoral flow-voids and a salt and pepper appearance may indicate hypervascularity. ${ }^{6}$ In addition, hypointense tumor margins on T2-weighted sequences suggesting paramagnetic effects from hemosiderin may also be seen. A "polar sign" has been described in T1 contrast enhanced and T2 images, representing subacute to chronic intratumoral hemorrhages within the lesions superior and inferior poles. ${ }^{6}$

Given enough time, erosion of the adjacent boney structures secondary to chronic bone compression can be seen on plain X-rays or even MRI imaging. ${ }^{1}$

\section{Histological Features}

Paraganglionic and neural crest cells have a common origin, and during embryogenesis, they migrate along the neural tube. ${ }^{5}$ Paragangliomas result from dysfunction of embryonic paraganglia cell migration or nonregression. ${ }^{5}$

The diagnosis of paragangliomas and the definition of their subtype is always made postoperatively from the histological study of the tumor. ${ }^{4}$ 
Paragangliomas are comprised of two cell types: chief cells and spindle shaped sustentacular cells, which are classically described as having a "Zellballen" or nesting pattern. ${ }^{1}$ In this case, neurofilament staining in spindle cells is present along with ganglion cells confirming a gangliocytic variation of a paraganglioma. ${ }^{1}$

\section{Conclusion}

Being slow-growing tumors, paragangliomas do not usually present with characteristic clinical findings. Their imaging is inconclusive, with multiple differential diagnoses. The final diagnosis can only be made with resource to the histological examination of the lesion. Given their benign, slow-growing, noninfiltrative nature, prognosis is very good after total surgical resection, with a low estimated recurrence (4\%). The insertion of the tumor on the filum terminale makes the surgical resection easier after the section of the filum, which guarantees a cure. However, there are reported cases of recurrence many years after surgical resection, supporting the need for a prolonged imagiological and clinical follow-up. When total resection isn't possible, adjuvant treatment with radiotherapy is recommended.

\section{Conflict of Interests}

The authors have no conflict of interests to declare.

\section{References}

1 Akbik OS, Floruta C, Chohan MO, SantaCruz KS, Carlson AP. Case Report A Unique Case of an Aggressive Gangliocytic Paraganglioma of the Filum Terminale. Case Rep Surg 2016
2 Hilmani S, Ngamasata T, Karkouri M, Elazahri A. Paraganglioma of the filum terminale mimicking neurinoma: Case report. Surg Neurol Int 2016;7(Suppl 5):S153-S155

3 Mishra T, Goel NA, Goel AH. Primary paraganglioma of the spine: A clinicopathological study of eight cases. J Craniovertebr Junction Spine 2014;5(01):20-24

4 Djindjian M, Ayache P, Brugières P, Malapert D, Baudrimont M, Poirier J. Giant gangliocytic paraganglioma of the filum terminale. Case report. J Neurosurg 1990;73(03):459-461

5 Murrone D, Romanelli B, Vella G, Ierardi A. Acute onset of paraganglioma of filum terminale: A case report and surgical treatment. Int J Surg Case Rep 2017;36:126-129

6 Méndez JC, Carrasco R, Prieto MA, Fandiño E, Blázquez J. Paraganglioma of the cauda equina: MR and angiographic findings. Radiol Case Rep 2019;14(10):1185-1187

7 Vural M, Arslantas A, Isiksoy S, Adapinar B, Atasoy M, Soylemezoglu F. Gangliocytic paraganglioma of the cauda equina with significant calcification: first description in pediatric age. Zentralbl Neurochir 2008;69(01):47-50

8 Llena JF, Wisoff HS, Hirano A. Gangliocytic paraganglioma in cauda equina region, with biochemical and neuropathological studies. Case report. J Neurosurg 1982;56(02): 280-282

9 Matschke J, Westphal M, Lamszus K. November 2004: intradural mass of the cauda equina in a woman in her early 60s. Brain Pathol 2005;15(02):169-170, 173

10 Moran CA, Rush W, Mena H. Primary spinal paragangliomas: a clinicopathological and immunohistochemical study of 30 cases. Histopathology 1997;31(02):167-173

11 London F, Mulquin N, Fervaille C, Lebecque O, Jankovski A. Radiologically atypical paraganglioma of the filum terminale as a rare cause of superficial siderosis of the central nervous system. Acta Neurol Belg 2020

12 Lerman RI, Kaplan ES, Daman L. Ganglioneuroma-paraganglioma of the intradural filum terminale. Case report. J Neurosurg 1972; 36:652-658 